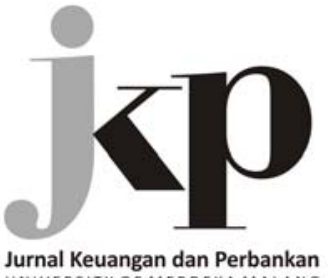

UNIVERSITY OF MERDEKA MALANG

Article history:

Received: 2019-01-23

Revised: 2019-04-12

Accepted: 2019-08-04

Keywords:

Banking; Diversification; Financial distress; Market concentration

JEL Classification: D4, G2

Kata kunci:

Bank; Diversifikasi; Financial distress; Konsentrasi pasar

$\square$ Corresponding Author:

Farida Titik Kristanti:

Tel +62 222011388

E-mail: faridatk@telkomuniversity.ac.id

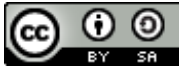

This is an open access

article under the CC-BY-SA license

\section{Market concentration, diversification, and financial distress in the Indonesian banking system}

\author{
Farida Titik Kristanti, Deannes Isynuwardhana, Sri Rahayu \\ Department of Accounting, Faculty of Economics and Business, Telkom University \\ Jl. Telekomunikasi, Terusan Buah Batu, Bandung, 40257, Indonesia
}

\section{Abstract}

The economic theory provides conflicting predictions about the relationship between the market structure of the banking industry and financial distress. The view of "concentration-fragility" argues that a banking structure that is more concentrated with a number of large banks is more vulnerable to financial fragility than a banking sector that is less concentrated with many banks. We examine how the concentration market, market share, and diversification affect the bank's financial distress. Using the purposive sampling method and data of listed banks in the 20142017 period, the results of statistical tests with logistic regression showed that market concentration has a positive effect on the bank's financial distress. The more concentrated the market, the greater the probability of the occurrence of financial distress in Indonesian banks. We also prove the validity of the SCP (The StructureConduct-Performance) hypothesis and efficiency hypothesis. Therefore, regulations need to be made in order to reduce this highly concentrated market so that the probability of financial distress decreases.

\section{Abstrak}

Teori ekonomi memberikan prediksi yang bertentangan tentang hubungan antara struktur pasar industri perbankan dan kesulitan keuangan. Pandangan tentang "concentration-fragility" berpendapat bahwa struktur perbankan yang lebih terkonsentrasi dengan beberapa bank besar lebih rentan terhadap kerapuhan keuangan daripada sektor perbankan yang kurang terkonsentrasi dengan banyak bank. Kami menganalisis bagaimana dampak konsentrasi pasar, pangsa pasar, dan diversifikasi terhadap financial distress bank. Dengan menggunakan metode purposive sampling dan data bank yang listed pada periode 2014-2017, hasil pengujian statistik dengan regresi logistik menunjukkan bahwa konsentrasi pasar berpengaruh positif terhadap financial distress bank. Semakin terkonsentrasi pasar, semakin besar juga probabilitas terjadinya financial distress bank. Kami juga membuktikan berlakunya SCP (The Structure-Conduct-Performance) hypothesis dan efficiency hypothesis. Oleh karena itu, regulator perlu mengatur agar mengurangi konsentrasi pasar perbankan sehingga terhindar dari financial distress.

How to Cite: Kristanti, F. T., Isynuwardhana, D., \& Rahayu, S. (2019). Market concentration, diversification, and financial distress in the Indonesian banking system. Jurnal Keuangan dan Perbankan, 23(4), 514-524. https:/ / doi.org/10.26905/jkdp.v23i4.2693 


\section{Market concentration, diversification, and financial distress in the Indonesian banking system}

Farida Titik Kristanti, Deannes Isynuwardhana, Sri Rahayu

\section{Introduction}

Financial distress is a condition in which a company is unable to pay its usual obligations before the company/bank goes bankrupt. Given the enormous impact on the economy, the bank sector must be managed very prudently. A robust banking system is very important to achieve sustainable economic growth for a country, especially developing countries (Levin, 1999). To achieve this capacity, developing country governments significantly liberalize financial markets and reform the financial sector (Nguyen, 2018).

According to Hendra \& Hartomo (2017), the Indonesian banking industry has become more competitive with major changes in recent years. The structure of the banking industry is still not optimal, so it is necessary to strengthen the industrial structure from both concentration and market share.

Market structure is an important variable to study in the industrial economy because it will affect the behavior and performance of companies in the industry (Naylah, 2010). Allen \& Gale (2004) state that low concentration in the banking system will erode bank market power which will affect the bank's present value of profit. This will make banks pursue risky policies that will increase the probability of distress in the banking system. Beck, Demirguc Kunt, \& Levine (2006) assesses the impact of the concentration of the banking market on the likelihood of suffering as a systematic crisis over the period 1980-1997 in Europe. The result was an increase in the concentration of banks not increasing the banking system fragility. Using panel data for the period 1997-2005, Heimeshoff \& Uhde (2008) find evidence that market concentration has a negative effect on bank health. The finding of Boyd, De Nicolo, \& Jalal (2006); De Nicoló \& Loukoianova (2007) is a significant positive effect between bank concentration and bank failure risk. Berger, Kappler, \& Turk Arriss (2017) found the fact that an increase in market power would increase loan risk (non-perform- ing loans). Cipollini \& Fiordelisi (2009) state that there is a positive influence between market concentration and financial distress. Meanwhile, Fu, Lin, \& Molyneux (2014) find evidence that there is a large shift in the average bank risk exposure that affected banking stability accompanied by a gradual increase in bank concentration. In Indonesia, Hendra \& Hartomo (2017) find evidence that market concentration with an $\mathrm{HHI}$ proxy shows a positive influence on bank risk, but the ratio proxy of concentration shows no influence on the bank's risk.

Market share reflects the current competitive position that companies can get on the market (Genchev, 2012). According to him, in these three decades, there have been many empirical studies related to market share and profitability. Laverty (2001) states that the relationship between market share and profitability is the most widely studied in management research. Genchev's study (2012) find evidence that there is no significant influence between market share and profitability of banks in Bulgaria. Mirzaei \& Mirzaei (2011) study shows that market share has a significant effect on bank profitability in developed countries, but not for developing countries. The study of Buzzell (2004) shows a positive influence between market share and bank profitability. Meanwhile in Indonesia, the study of Hendra \& Hartomo (2017) shows no influence between market share and bank risk.

Goetz (2012) find evidence that increasing geographic diversification had the opposite effect on firm value. Cotugno \& Stefanelli (2012) in Italy prove that there is a positive influence between bank diversification and performance. The study of Bernini \& Brighi (2012) shows greater diversification at the local level determined the increase in cost inefficiency. Hirtle (2009) find evidence that a large increase in the branch is precisely lowering the performance of the bank, whereas Deng \& Elyasiani (2008) prove that geographical diversification positively affected risks and negativity towards firm value. 
Previous studies on market concentration, market share and diversification mostly use performance as a dependent variable. There have not been many studies using financial distress. Therefore, researchers are interested in analyzing the behavior of the banking industry in Indonesia which has distinctive characteristics with the industrial organization approach. This study was conducted to assess how the effects market concentration, market share, and diversification to the financial distress of banks in Indonesia. Market concentration uses proxy CR3 (the concentration ratio of the 3 largest commercial banks) and HHI (Herfindahl-Hirschman Index). Bank Diversification uses various proxies, namely the number of branches owned. Understanding this can be used as an early warning for stakeholders so that it can prevent the bank from entering into a worse financial situation. The empirical results of this study are expected to contribute to the development of knowledge, especially financial management on the topic of financial distress, and the cause is the structure of competition.

\section{Hypotheses Development}

The Structure-Conduct-Performance (SCP) paradigm is a paradigm of industrial economics that connects elements of a market structure with the behavior and performance of an industry. The SCP paradigm shows that market structure affects the performance of companies in an industry. The SCP paradigm, which was an industrial-organizational structure theory developed by Bain (1951), was originally used in the manufacturing industry in the USA. Later Caves (1982) conducted a study on the banking industry, and the results showed that at a time when the market concentration was high, it would prevent the entry of competitors, and increasing market concentration would influence the behavior of banks to carry out collusive actions. Gilbert (1984) revealed that market structure will affect corporate behavior which will ultimately affect the company's performance in aggregate. This is because market-powered companies will be able to increase company profits. According to SCP, a high level of concentration is an indicator of market structure, and the higher the level of concentration the more market power they will have. This market power is expected to be able to make banks obtain high profits so as to reduce the probability of banks experiencing financial distress. In the banking industry, measurement of concentration levels can use asset share, revenue share, and share of third-party funds.

\section{Market concentration and financial distress}

Market concentration is the market share held by the bank relative to the industry. Concentration occurs due to the strength of some of the largest banks. The traditional hypothesis assumes that concentration is the proxy of market power. According to Naylah (2010), greater market concentration makes the cost of collusion lower so that companies in the industry will get supernormal profits. Supernormal profits will make the company avoid financial distress. This study uses the Herfindahl Index and concentration ratio as a proxy market concentration. The Matutes \& Vives (2000) study in Europe in the period 1997-2005; Uhde \& Helmeshoff (2009) find evidence that market concentration has a negative effect on the financial health of banks in Europe as measured by the z-score.

$H_{1}$ : the higher the concentration, the lower the bank's financial distress

\section{Market share and financial distress}

The efficient structure hypothesis states that market share and market concentration are proxies of company efficiency. More efficient companies will be able to get a larger market share so the industry is also more concentrated. Because the market is concentrated, the bank will get a supernormal profit which makes the bank avoid financial distress. In line with Cotugno \& Stefanelli (2012), 
the higher the market share, the greater the company's performance, which means it will reduce the probability of financial distress.

$\mathrm{H}_{2}$ : the higher the market share, the lower the bank's financial distress

\section{Geographical diversification and financial distress}

Market Power Theory (Porter, 1980) argues that the positioning of a company in its environment uses a variety of strategies that distinguish it among its competitors. One of the strategies to win the competition is through diversification (Barney, 2002) which makes the company able to build market power. According to Palich, Carini, \& Seaman (2000), companies that have market power can easily control the market by offering discounts, cross subsidies and applying reciprocal purchasing and selling as tools to prevent potential competitors entering the market. So, diversification will make the company more profitable and able to avoid financial distress. Denis, Denis, \& Sarin (1997) studies prove that the decrease in diversification associated with corporate external controls threatens financial distress.

$H_{3}$ : the higher the diversification, the lower the financial distress Bank

\section{Method, Data, and Analysis}

This study will examine whether the concentration, market share, and geographical diversification influence the financial distress of banks in Indonesia. Purposive random sampling is used with the banks' criteria to complete research data during the study period. There are 33 sample banks selected from 43 banks listed on IDX for the period 20132017 because there are 10 banks that do not have complete data during the study period.

Logistic regression is used because the dependent variable uses a dummy variable that has two alternative values. Value 1 is given if banks experience financial distress and value 0 if vice versa. The fit model is assessed using the likelihood function, whereas Hosmer and Lemeshow's Goodness of Fit Test is used to test the null hypothesis. If the Hosmer and Lemeshow's Goodness of Fit Test statistics are equal to or less than $5 \%$, the null hypothesis is rejected. If this happens, the model is not good, and the model cannot predict the value of the observations.

This study uses two (2) proxies for the dependent variable. For model A, the bank is included in the criteria of financial distress if it has an interest cost ratio (ICR) equal to 1 and does not experience financial distress if ICR $=0$, as used by Kuncoro \& Agustina (2016). ICR shows banking efficiency, if the Bank has an ICR greater than one (1) shows that the bank is able to finance its interest expense so that it has a positive pre-tax profit so that the bank is certain not to experience financial distress. Meanwhile, for model B, the bank is included in the criteria of financial distress if for two years the NPL value is in a fourth of quartile from the sample data distribution (Baklouti, Gautier, \& Affes, 2016) or greater than the third quartile (Messai \& Gallali, 2015). If the NPL owned by the bank exceeds $3 / 4$ of the normal distribution of the industry, it will be difficult for banks not to experience financial distress.

The concentration ratio is used as the basic calculations, asset-based, revenue-based, and thirdparty funds base for measuring industry concentration. CR3 is the percentage of mastery of the three biggest companies in the industry (Wibowo, 2016). The variables commonly used are those of assets, third-party funds, and relevant credit in the banking industry. The value of the ratio is between 0 (leading to perfect competition market) to 1 (monopoly market). CR3 will be used to measure the assets of the three largest banks.

$$
C R 4=\sum_{i=1}^{3} \frac{\text { Total asset of } 4 \text { biggest banks }}{\text { Total asset of industries }}
$$




\section{Jurnal Keuangan dan Perbankan}

Volume 23, Issue 4, October 2019: 514-524

The Herfindahl-Hirschman Index (HHI) uses the relative size and number of banks operating in the banking industry. This HHI assumes, if there is only one bank in the banking sector, then the structure is a monopoly; whereas if the value is close to 0 , it means that there are a large number of banks in the banking industry that have relatively the same size. The higher the HHI value, the higher the level of bank concentration and vice versa. Some researchers who use HHI are Elsas, Hackethal, \& Holzhäuser (2010), and Mochabo, Ombaba, \& Ondiek (2017).

$$
H H I=\sum_{i=1}^{H} \frac{\text { Total revenue of bank services }}{\text { Total revenue of industry }}
$$

Market share is calculated from the calculation of total third-party funds owned by a bank relative to the total third-party funds of all banks in the industry.

MS $=\frac{\text { Total funds of third party }}{\text { Total funds of third party of Industry }}$

Geographical Diversification is measured using natural logs of the number of branch offices owned by banks (Mochabo, Ombaba, \& Ondiek, 2017)

Logistic regression is used to test whether the probability of the occurrence of financial distress can be predicted by the dependent variable which is a mixture of metric (continuous) and categorical (non-metric) variables (Ghozali, 2009). The model used is:

$$
\begin{aligned}
\operatorname{Ln} \frac{P}{1-P}= & \beta_{0}+\beta_{1} C R 3+\beta_{2} H H I+\beta_{3} M S+\beta_{4} G D+\beta_{5} L D R+ \\
& \beta_{6} C A R+\beta_{7} N I M+\beta_{5} O R
\end{aligned}
$$

Where: LDR (Loan Deposit Ratio), CAR (Capital Adequacy Ratio), ROA (Return on Assets), NIM
(Net Interest Margin), and OR (Operating Risk) are control variables. LDR is the ratio of total loans to total third party funds. CAR is capital-to-risk weighted assets ratio. OR is operating expense to operating income.

The model will be tested using a different proxy financial distress. Model A uses a proxy income cost ratio (ICR) for the dependent variable. Next model B uses a proxy of the fourth of NPL quartile proxy from the distribution of sample data.

\section{Results}

Table 1 shows the descriptive statistic of data. Mean HHI value of 0.118 indicate that banks in Indonesia tend to be not concentrated. This condition was reinforced due to the mean CR4 value of 0.123 , which indicate that banks in Indonesia tend to be perfect competition market. Likewise, the mean market share data is relatively minor, which is equal to 0.002. Geographical diversification as measured by the number of branches owned by a bank has a mean value of 2,219 with a minimum value of 0.903 and a maximum value of 4.0272 , indicates that the average bank in Indonesia is relatively undiversified.

The test results of the fit model in Table 2 show all models fit, so the model is worthy of use. However, the model with ICR as a proxy for financial distress shows the number of Nagelkerke $R_{2}$ which is relatively small when compared to NPL as a proxy for financial distress. Simultaneously, all independent variables that affect the probability of financial distress are 42.1 percent (FD (ICR)) and 37.1 percent (FD (> Q3 NPL)).

Table 3 shows the results of statistical test using logistic regression. The results show that for Model A (using ICR as an indicator), only geographical diversification and LDR affected the bank's financial distress in Indonesia. As for model B (using NPL as an indicator of distress) only CAR, NIM and BOPO affected financial distress. 
From the statistical test results, a model can be made as follows:

Model A

$\operatorname{Ln} \frac{p}{1-p}=3.572-30.234$ CR3-37.780 HHl $+1502.810 \mathrm{MS}+1.161 \mathrm{GD}-$

0.041 LDR-0.020 CAR+0.064 NIM-0.002 OR

Model B

$\operatorname{Ln} \frac{p}{1-p}=-20.935+102.167$ CR3 $+69.038 \mathrm{HHI}-2477.501 \mathrm{MS}$

0.161 GD+0.016 LDR-0.079 CAR+0.283 NM+0.0!

\section{Discussion}

The average banks in Indonesia do not experience financial distress, both seen using ICR and NPL proxies. This is indicated by the mean value of ICR and NPL which is far from the maximum value (Table 1). The data of descriptive statistics show that all variables have a lower standard deviation than the mean. It means that they do not possess a high gap between maximum and minimum value.

According to Jumono, Abdurrahman, \& Mala (2017), the level of market concentration is said to

Table 1. Descriptive statistics

\begin{tabular}{llrrrr}
\hline & N & Minimum & Maximum & Mean & Std. Deviation \\
\hline$H H I$ & 210 & 0.117 & 0.118 & 0.118 & 0.000 \\
CR4 & 210 & 0.092 & 0.152 & 0.121 & 0.021 \\
MS & 210 & 0.001 & 0.003 & 0.002 & 0.000 \\
GEODIV & 210 & 0.903 & 4.027 & 2.219 & 0.730 \\
CAR & 210 & 1.020 & 87.490 & 19.607 & 8.120 \\
NIM & 210 & 0.240 & 13.040 & 5.074 & 1.732 \\
OR & 210 & 9.040 & 235.200 & 89.944 & 23.375 \\
LDR & 210 & 45.720 & 140.720 & 85.372 & 12.538 \\
FD (ICR) & 210 & 0.000 & 1.000 & 0.162 & 0.369 \\
$F D(>Q 3 ~ N P L)$ & 210 & 0.000 & 1.000 & 0.314 & 0.465 \\
\hline
\end{tabular}

Table 2. The test result of model fit

\begin{tabular}{lll}
\hline & Model A (FD =ICR) & Model B (FD is >Q3 NPL) \\
\hline Omnibus test & CS 24.712 (sig 0.002) & CS 50.543 (Sig 0.000) \\
Nagelkerke R ${ }^{2}$ & $18.9 \%$ & $30.0 \%$ \\
H \& L test & CS 19.597 (sig 0.445) & CS 5.742 (Sig 0.949) \\
\hline
\end{tabular}

Table 3. Estimation results

\begin{tabular}{lrrrr}
\hline & \multicolumn{2}{c}{ Model A (FD =ICR) } & \multicolumn{2}{c}{ Model B (FD is >Q3 NPL) } \\
\cline { 2 - 5 } & B & Sig. & B & -20.935 \\
Sig. & 0.393 \\
CR4 & 3.572 & 0.904 & 102.160 & 0.436 \\
HHI & -30.234 & 0.650 & 69.038 & 0.684 \\
MS & -37.780 & 0.853 & -2477.501 & 0.570 \\
GD & 1502.810 & 0.776 & -0.160 & 0.574 \\
LDR & $1.161^{* * *}$ & 0.002 & 0.016 & 0.303 \\
CAR & $-0.041^{* *}$ & 0.023 & $-0.079^{*}$ & 0.053 \\
NIM & -0.020 & 0.576 & $0.283^{* *}$ & 0.024 \\
BOPO & 0.064 & 0.635 & $0.053^{* * *}$ & 0.000 \\
Percentage correct & -0.002 & 0.855 & 79.000 & \\
\hline
\end{tabular}

*) Significant at alpha $10 \%,{ }^{* *}$ ) Significant at alpha $5 \%,{ }^{* * *}$ ) Significant at alpha $1 \%$ 
be highly oligopoly if the value of CR4 is more than $60 \% ; 0<\mathrm{CR} 4<40 \%$ is effective competition or monopolistic competition. The data in table 2 show that the average number of the four largest banks in Indonesia has a market share of below $75 \%$ so that it can be stated that the market structure is not highly concentrated. Meanwhile, according to the criteria of the Business Supervision Commission (Hendra \& Hartomo, 2017), if the HHI value is> 0.18, then it is included in the high concentration. According to Jumono, Abdurrahman, \& Mala (2017) if the HHI $<1$, the market is monopolistic. The HHI value of banking in Indonesia is 0.1126 . It can be said that Indonesian banks do not have a highly concentrated market structure. Variable HHI shows that banking in Indonesia tends to a monopolistic market structure.

Model A with ICR as a proxy financial distress gives model accuracy of $85.7 \%$. It gives higher accuracy than if using NPL proxy in model B (Table 2). Although the level of accuracy of Model A is greater than that of model $\mathrm{B}$, only geographical diversification variable has a significant effect on the probability of financial distress.

In Model A, the statistical test results show market concentration (CR4 and HHI) do not have a significant effect on the financial distress in both models. Although it is not significant, the results show that the more concentrated the market, the lower the probability of the bank experiencing financial distress. This result is in line with the study of Mirzaei \& Mirzaei (2011) and Hendra \& Hartomo (2017), but it is not in line with the study of Mulyaningsih \& Daly (2011); Fu et al. (2014); Yudaruddin (2014).

Geographical diversification has a significant positive effect on the probability of bank financial distress in Indonesia. The increase of geographical diversification banks will increase the probability of financial distress bank. This proves that geographical diversification is a determinant factor for financial distress. The descriptive statistics show that the average banks in Indonesia have a positive profit and only a few banks are included in the criteria for financial distress, either using ICR or NPL proxies. This is natural because banks are indeed managed very prudently, and the banking industry is a highly regulated industry in order to be able to minimize the big negative impacts that might affect the country's economy.

Model B that uses NPL as proxy financial distress turns out to show different results. There are no significant effects between market concentration, geographical diversification, and market share to the probability of financial distress bank. Market concentration has a positive effect on the probability of a bank experiencing financial. The higher the level of concentration of banks in Indonesia, the greater the probability of banks experiencing financial distress. This result is in line with the study of Hendra \& Hartomo (2017). Likewise, market share and geographical diversification have negative effects on financial distress bank.

Both models (A and B) show the same results; there are no significant effects between market concentration and financial distress bank. However, the direction shows that the higher the market concentration, the lower the probability of banks experiencing financial distress. The results are not like those of Boyd \& De Nicolo (2005); Boyd, De Nicolo, \& Jalal (2006); Uhde \& Heimeshoff, (2009); Fu, et al. (2014); Pawlowska (2016), which show that market concentration can also be a source of bank fragility. Meanwhile, according to Demirguc-Kunt \& Kane (2002) which are most costly for developing countries. However, whether the market concentration is a source of stability or not, the bank's financial situation is strongly influenced by the performance of the real economy (Dell'Ariccia, Igan, \& Laeven, 2012). This real economic activity is greatly influenced by the world economic situation. Market concentration also has a negative influence on the risktaking and profitability of banks in developing coun- 
tries, such as Indonesia (Mirzaei \& Mirzaei, 2011). This reinforces this study because high concentration will reduce the bank's profitability, which in turn will increase the probability of financial distress.

Market share also does not have a significant effect on the bank's financial distress for the two models used. This is in line with the study of Hendra \& Hartomo (2017) who found evidence that there was an insignificant influence in the positive direction between market share and risk-taking. The higher the market share, the higher the risk taken by the bank will result in a high return. Yet, these results are not in accordance with Matutes \& Vives (2000) who find positive results between market share and risk-taking.

Bank diversification has a significant effect on financial distress in Model A but not significant in Model B. In model A, financial distress was measured with income cost ratio, whereas in model B, it was measured with the non-performing loan. When measured with ICR, the number of branches from a bank will increase its financial distress because the more branches they have, the higher the cost, so the probability of a bank having financial distress is also increasing. The study of Cai, $\mathrm{Xu}, \&$ Zeng (2016) states that diversification not only improves profitability but also increases operating costs. Although the bank is a type of business that is regulated very prudently and high regulated so that the bank's policy to add branches has been carried out with economic considerations. This is in line with the study of Mochabo, Ombaba, \& Ondiek (2017) in Kenya which finds evidence of a positive influence between the two variables.

\section{Conclusion, Limitations, and Suggestions Conclusion}

This study shows that market structure (HHI and CR4) is not the factor that affects the bank's financial distress, whether it used NPL or ICR as a financial distress indicator. This study also proves the validity of the SCP hypothesis. The bank structure in Indonesia does not tend to be concentrated. However, the increase in the geographical diversification of the Banks actually increases the probability of their financial distress. Because geographical diversification is an important variable for companies to avoid financial distress, banks must increase the number of branches. The test results also show that the level of accuracy using ICR as a proxy for financial distress is higher than using an NPL proxy.

\section{Limitations and suggestions}

There are two weaknesses to this study. Firstly, the financial distress indicators used in this study are only ICR and NPL. Secondly, there is no separation between conventional and commercial banks. Therefore, for further research, researchers can use other financial distress proxies such as $\mathrm{z}$ scores that better reflect the risk of bank decision making. Otherwise, the next researcher can compare conventional banks with Islamic banks that have different risk preferences.

\section{Acknowledgment}

This paper is one of the outputs of the Fundamental Grants of the Directorate General of Higher Education (DIKTI) of 2018 funding.

\section{References}

Allen, F., \& Gale D. (2004). Competition and financial stability. Journal of Money, Credit, and Banking, $36(3), 453-480$.

Bain, J. S. (1951). Relation of profit rate to industry concentration: American manufacturing, 1936-1940. The Quarterly Journal of Economics, 65(3), 293-324. https://doi.org/10.2307/1882217 


\section{Jurnal Keuangan dan Perbankan}

Volume 23, Issue 4, October 2019: 514-524

Baklouti, N., Gautier, F., \& Affes, H. (2016). Corporate governance and financial distress of European commercial banks. Journal of Business Studies Quarterly, 7(3), 75-96.

Barney, J. B. (2002). Strategic Management: From Informed Conversation to Academic Discipline. The Academy of Management Executive (1993-2005), 16(2), 53-57. https://doi.org/10.5465/ame.2002.7173521

Beck, T., Demirguc Kunt, A., \& Levine, R. (2006). Bank concentration, competition, and crises: First results. Journal of Banking and Finance, 30(5), 1581 1603. https://doi.org/10.1016/j.jbankfin.2005.05.010

Berger, A. N., Kappler, L. F., \& Turk Ariss, R. (2017). Bank competition and financial stability. Handbook of Competition in Banking and Finance, 10, 185-204. https://doi.org/10.4337/9781785363306.00018

Bernini, C., \& Brighi, P. (2012). Distance and efficiency in the Italian banking system. In J. Fernández De Guevara Radoselovics \& J. Pastor Monsálvez (eds.) Modern Bank Behaviour. Palgrave Macmillan, 6186. https://doi.org/10.1057/9781137001863.0011

Boyd, J. H., De Nicolo, G., \& Jalal, A. M. (2006). Bank risk taking and competition revisited: New theory and new evidence. IMF Working Paper, 06(297). https://doi.org/10.5089/9781451865578.001

Boyd, J. H., \& De Nicolo, G. (2005). The theory of bank risk-taking and competition revisited. The Journal of Finance, 60(3), 1329-1343. https://doi.org/10.1111/j.1540-6261.2005.00763.x

Buzzell, R. D. (2004). The PIMS program of strategy research: A retrospective appraisal. Journal of Business Research, 57(5), 478-483. https://doi.org/10.1016/s0148-2963(02)00314-4

Cai, W., Xu, F., \& Zeng, C. (2016). Geographical diversification and bank performance: Evidence from China. Economics Letter, 147, 96-98. https://doi.org/10.1016/j.econlet.2016.08.022

Caves, R. (1982). American industry: Structure, conduct, performance. Englewood Cliffs, NJ, USA: PrenticeHall, Inc. Journal of Macroeconomics, 4(4), 489. https://doi.org/10.1016/0164-0704(82)90069-6

Cipollini, A., \& Fiordelisi, F. (2009). The impact of bank concentration on financial distress: The case of the European banking system. EMFI Working Paper No.2. https://doi.org/10.2139/ssrn.1343441

Cotugno, M., \& Stefanelli, V. (2012). Geographical and product diversification during instability financial period: Good or bad for banks? SSRN Electronic Journal. https://doi.org/10.2139/ssrn.1989919

De Nicoló, G., \& Loukoianova, E. (2007). Bank ownership, market structure, and risk. IMF Working Paper, 07(215). https://doi.org/10.5089/9781451867794.001

Dell'Ariccia, G., Igan, D., \& Laeven, L. A. (2012). Credit booms and lending standards: Evidence from the subprime-mortgage market. Journal of Money, Credit, and Banking, 44 (2-3), 367-384.

https://doi.org/10.1111/j.1538-4616.2011.00491.x

Demirguc-Kunt, A., \& Kane, E. J. (2002). Deposit insurance around the globe: Where does it work? Journal of Economic Perspectives, 16(2), 175-195. https://doi.org/10.1257/0895330027319

Deng, S. E., \& Elyasiani, E. (2008). Geographic diversification, bank holding company value, and risk. Journal of Money Credit and Banking, 40(6), 1217-1238.

https://doi.org/10.1111/j.1538-4616.2008.00154.x

Denis, D. J., Denis, D. K., \& Sarin, A. (1997). Agency problems, equity ownership, and corporate diversification. The journal of finance, 52(1), 135-160. https://doi.org/10.2307/2329559

Elsas, R., Hackethal, A., \& Holzhäuser, M. (2010). The anatomy of bank diversification. Journal of Banking o Finance, 34(6), 1274-1287. https://doi.org/10.1016/j.jbankfin.2009.11.024 


\section{Market concentration, diversification, and financial distress in the Indonesian banking system \\ Farida Titik Kristanti, Deannes Isynuwardhana, Sri Rahayu}

Fu, X. M, Lin, Y. R., \& Molyneux, P. (2014). Bank competition and financial stability in Asia Pacific. SSRN Electronic Journal. https://doi.org/10.2139/ssrn.2136819

Genchev. (2012).The bank's profitability. Review of Applied Socio-Economic Research, 3(1), 87-97.

Ghozali, I. (2009). Analisis Multivariate Lanjutan dengan SPSS. Badan Penerbit Universitas Diponegoro.

Gilbert, R. A. (1984). Bank market structure and competition: A survey. Journal of Money, Credit, and Banking, 16(4), 617-645. https://doi.org/10.2307/1992096

Goetz, M. R. (2012). Bank diversification, market structure, and bank risk-taking: Theory and evidence from U.S. commercial banks. Federal Reserve Bank of Boston. SSRN Electronic Journal. https://doi.org/10.2139/ssrn.2651161

Heimeshoff, U., \& Uhde, A. (2008). Consolidation in banking and financial stability in Europe. Journal of Banking and Finance, 33(7), 1299-1311. https://doi.org/10.1016/j.jbankfin.2009.01.006

Hendra, S. T. N., \& Hartomo, D. D. (2017). Pengaruh konsentrasi dan pangsa pasar terhadap pengambilan risiko bank. Jurnal Bisnis \& Manajemen, 17(2), 35-50. https://doi.org/10.20961/jbm.v17i2.17176

Hirtle, B. (2009). Credit derivatives and bank credit supply. Journal of Financial Intermediation, 18 (2), 125 150. https://doi.org/10.1016/j.jfi.2008.08.001

Jumono, S., Abdurrahman, \& Mala, C. M. F. (2017). Market concentration index and performance: Evidence from Indonesian banking industry. International Journal of Economics and Financial Issues, 7(2), 249. 258.

Kuncoro, S., \& Agustina. (2016). Factors to predict the financial distress condition of the banking listed in the Indonesia Stock Exchange. Accounting Analysis Journal, 6(1), 39-47.

Laverty K. J. (2001). Market share, profits, and business strategy. Management Decision, 39(8), $607-618$. https://doi.org/10.1108/eum0000000005860

Levin, R. (1999). Financial development and economic growth: Views and agenda. Policy Research Working Papers. World Bank Grup. https://doi.org/10.1596/1813-9450-1678

Matutes, C. and X. Vives. (2000). Imperfect competition, risk-taking, and regulation in banking. European Economic Review, 44(1), 1-34. https:/doi.org/10.1016/s0014-2921(98)00057-9

Messai, A. S., \& Gallali, M. I. (2015). Financial leading indicators of banking distress: A micro prudential approach - Evidence from Europe. Asian Social Issues, 11(21), 78-90. https://doi.org/10.5539/ass.v11n21p78

Mirzaei, A., \& Mirzaei, Z. (2011). Bank-specific and macroeconomic determinants of profitability in Middle Eastern banking. Iranian Economic Review, 15(29), 101-128.

Mochabo, I. M., Ombaba, K. B. M., \& Ondiek, B. A. (2017). Effect of bank diversification on the financial distress of commercial banks listed at the Nairobi Securities Exchange, Kenya. International Journal of Scientific Research and Management, 5(11), 7329-7343. https://doi.org/10.18535/ijsrm/v5i11.01

Mulyaningsih, T., \& Daly, A. (2011). Competitive conditions in banking industry: An empirical analysis of the consolidation, competition, and concentration in the Indonesia banking industry between 2001 and 2009. Buletin Ekonomi Moneter dan Perbankan, 14(2), 141-175. https://doi.org/10.21098/bemp.v14i2.83

Naylah, M. (2010). Pengaruh struktur pasar terhadap kinerja industri perbankan Indonesia. Thesis. (Unpublished). Semarang: Universitas Diponegoro. 
Nguyen, T. L. A. (2018). Diversification and bank efficiency in six ASEAN countries. Global Finance Journal, 37, 57-78. https://doi.org/10.1016/j.gfj.2018.04.004

Palich, L. E., Carini, G. R., \& Seaman, S. L. (2000). The impact of internationalization on the diversification-performance relationship: A replication and extension of prior research. Journal of Business Research, 48(1), 43-54. https://doi.org/10.1016/s0148-2963(98)00074-5

Pawlowska, M. (2016). Does the size and market structure of the banking sector have an effect on the financial stability of the European Union? The Journal of Economic Asymmetries, 14, 112-127.

Porter, M. E. (1980). Competitive Strategy: Techniques for Analyzing Industries and Competitors. New York: Free Press. https://doi.org/10.1016/0019-8501(82)90025-6

Uhde, A., \& Heimeshoff, U. (2009). Consolidation in banking and financial stability in Europe further evidence. Journal of Banking and Finance, 33, 1299-1311. https://doi.org/10.1016/j.jbankfin.2009.01.006

Wibowo, B. (2016). Bank scale of economies, banking industry concentration, and competition level: The Indonesian case. Jurnal Bisnis \& Manajemen, 17(1), 58-72. https://doi.org/10.24198/jbm.v17i1.7

Wulandari, Y., Musdholifah, \& Kusairi, S. (2017). The Impact of macroeconomic and internal factors on banking distress. International Journal of Economics and Financial Issues, 7(3), 429-436.

Yudaruddin, R. (2014). Dampak tingkat konsentrasi terhadap kinerja dan stabilitas perbankan di Indonesia tahun 2003-2013. Jurnal Keuangan dan Perbankan, 18(2), 278-286. 